\title{
Opportunities for Increasing Efficiency by Public Utility Organizations
}

\author{
György Kocziszky
}

Mariann Veresné Somosi

\begin{abstract}
The result and expenditure based performance measurement and evaluation are much the same age in the private sector with the modern enterprise theory. It is enough to make an overview of the Anglo-Saxon and German literature between the two world wars, which pays significant attention on the economic and work organizational tools and methods of enterprise level performance measurement and improvement. The public sphere and within this the issue of operational and economic efficiency measurement of public utility organizations has got a more modest past and methodological framework, although its significance is not smaller. The authors in their research make an attempt to compensate it, when they make suggestions for the performance evaluation process and methods of public utility organizations.
\end{abstract}

Keywords: performance management, public utility organizations, public economics, integrity JEL codes: D73, H83, P43

\section{Introduction}

\section{Function, national economic importance and role of public utility organizations}

The role of state and market, and their relationship is one of the stressed questions of economic theory and economic policy, but also one of the most disputed questions from several aspects (e.g.: social policy, ethics, competitiveness, regulation etc.).

It represents the values of a given society how the needful resources are secured for the state engagement, what are the aspects of allocation and what efficiency has the utilization of resources. It reflects what the political elite consider as important: the low tax rates or the improvement of public services? This political decision influences basically the principles for the reallocation of resources, which in some cases does not meet the society's needs.

The satisfaction or non-satisfaction depends on the available resources and on the other hand on the efficiency of the resource utilization. That is why the operation of public utility companies is not alone an economic but also a social policy question.

The public services and service providers fulfil public needs, and because of this their financing comes partly or fully from public money (Figure 1). 


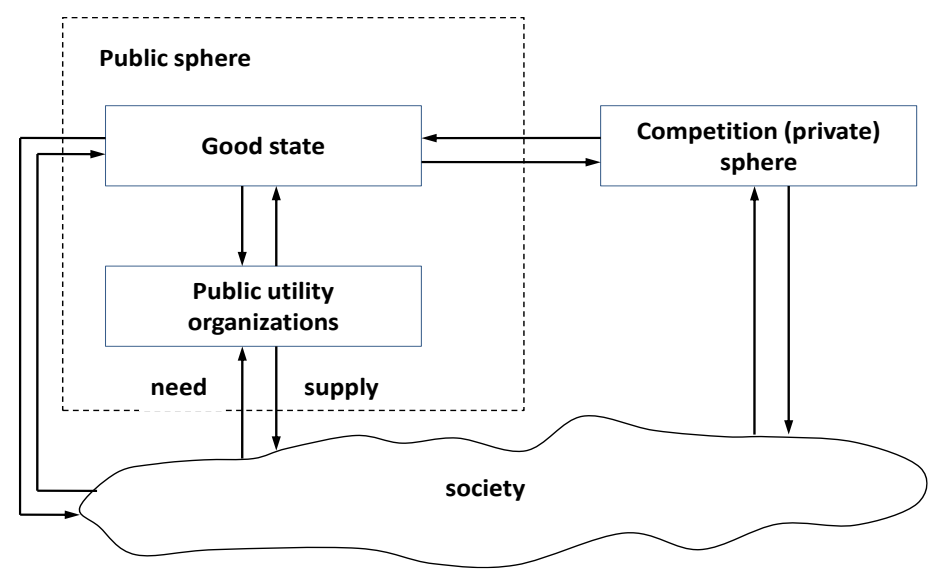

Figure 1. Logic of public resource creation and allocation

Source: own compilation

It is not easy to harmonize the resources (which are from above limited) and the increasing expectations (which sometimes do not have any upper limit). This fact can be verified also according the last three decades' national practice. It matters in what kind of efficiency the public utility organizations utilize the available resources for the public needs. That is why the government considers the improvement of the public services' efficiency as a high priority in the recent EU financing period (2014-2020).

The public utility organizations can be different according their objectives, ownership or control, and economic character (Figure 2).

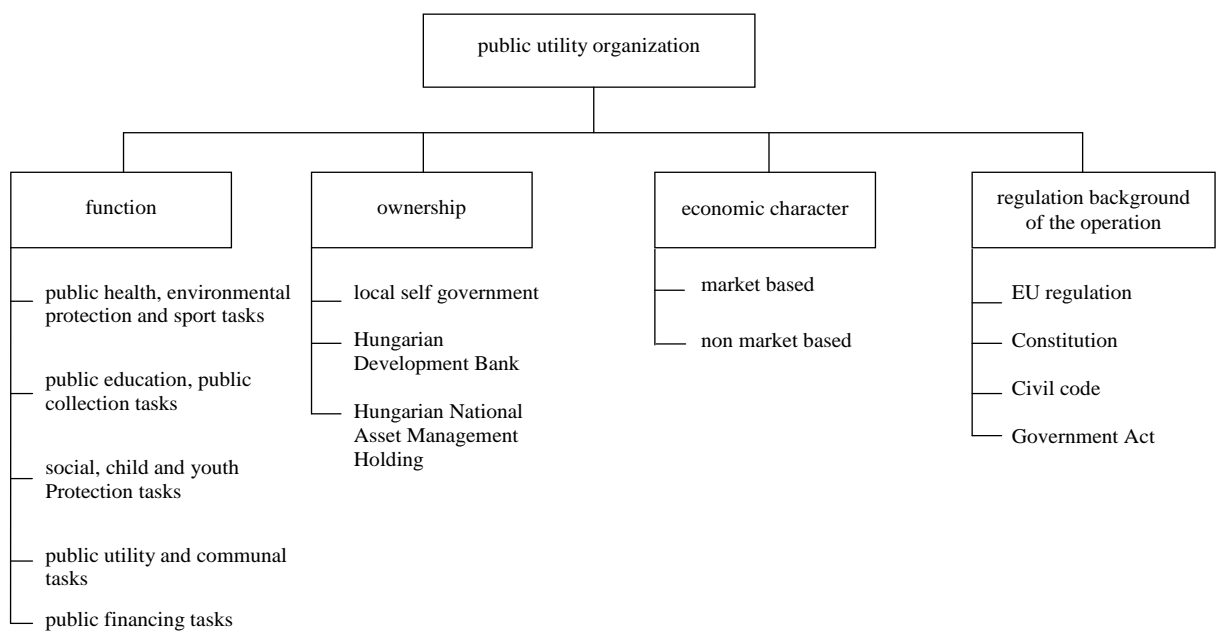

Figure 2. Typology of public utility organizations

Source: own compilation 
Their operating conditions are regulated through the EU regulations (e.g.: the $90^{\text {th }}$ clause of the Treaty; the CEC, 1996. etc.) and on the other hand through the national legislation. The first concentrates basically on the opportunities and limitations of state supports, while the second summarizes the performance regulations (which can be very different among the member states).

As it also the literature underlies the national economic role of the public utility organizations has changed and is changing depending on the liberal or welfare policy model (Leinhard, 2005; Reinermann, 2000; Pulay, 2012; Domokos, 2015).

As a result of the economic and social policy change happened after the governmental change in 2010 the state engagement has became greater in Hungary, which can be verified also through the increasing number of public utility organizations and the number of their employees. In this process the state share purchases have a significant role (Figure 3).

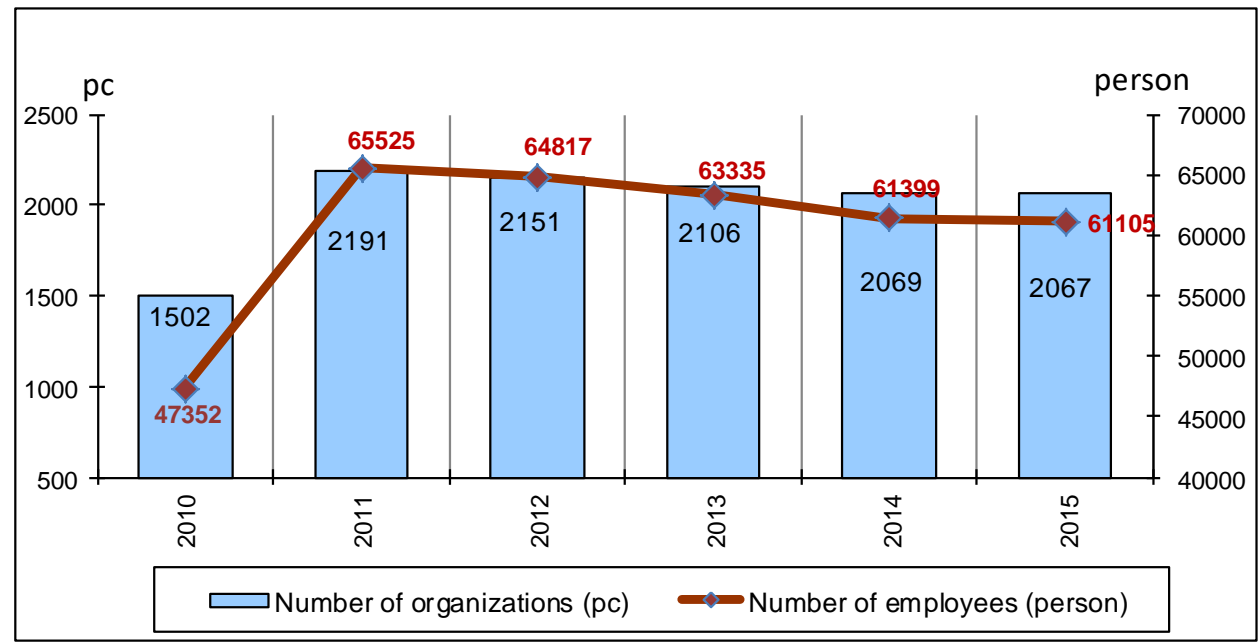

Figure 3. Change in the number and employment of public utility organizations

(Left axis - number of public utility organizations (pc); right axis - number of employees (person))

Source: own compilation

The operation area of the public utility companies has been changed in the last five years. In some sectors the state has assigned its ownership position, while in other areas beside his regulation role also his ownership role has appeared. Most of the companies are working in the utilities sector as a result of the last years' reprivatisation.

As an effect of the last years' profile deepening and investments the total balance sheet and tangible assets stock of public utility organizations has been increased (Table 1).

Table 1: The improvement of public utility organizations' balance sheet in Hungary (million Ft)

\begin{tabular}{|l|l|l|l|l|l|l|l|}
\hline & 2010 & 2011 & 2012 & 2013 & 2014 & 2015 & $\begin{array}{l}2015 / 2010 \\
(\%)\end{array}$ \\
\hline $\begin{array}{l}\text { Tangible } \\
\text { assets }\end{array}$ & $3,336,741.5$ & $3,487,431.1$ & $3,542,305.9$ & $4,049,029.4$ & $4,402,123.6$ & $4,763,807.5$ & 142.7 \\
\hline $\begin{array}{l}\text { Total } \\
\text { balance } \\
\text { sheet }\end{array}$ & $7,094,837.3$ & $7,890,750.8$ & $7,985,096.0$ & $9,314,145.2$ & $12,129,564.5$ & $13,795,142.0$ & 194.4 \\
\hline
\end{tabular}

Source: own edited based on the dates of the Registry Court 


\section{Operation of the public utility organizations}

The operation logic of the public utility sector is basically different from the private (competitive) sphere. While in the second type the basic goal is the profit, and the social responsibility is only a sub goal; the basic goal of the public services is the social responsibility. At the same time this goal can not save the management of any public utility organization from efficiency requirements. So the quality and efficiency of the public utility organizations' services and tasks is a sensible question not only from social policy aspects but also from economic aspects.

The losses in the operation of public utility organizations can be the results of external (institutional or control) and internal (economies of scale, competence, methodology, process controlling, ethics or assets management) causes (Figure 4).

The lack of resources is in most of the cases reality but it is not the only problem!

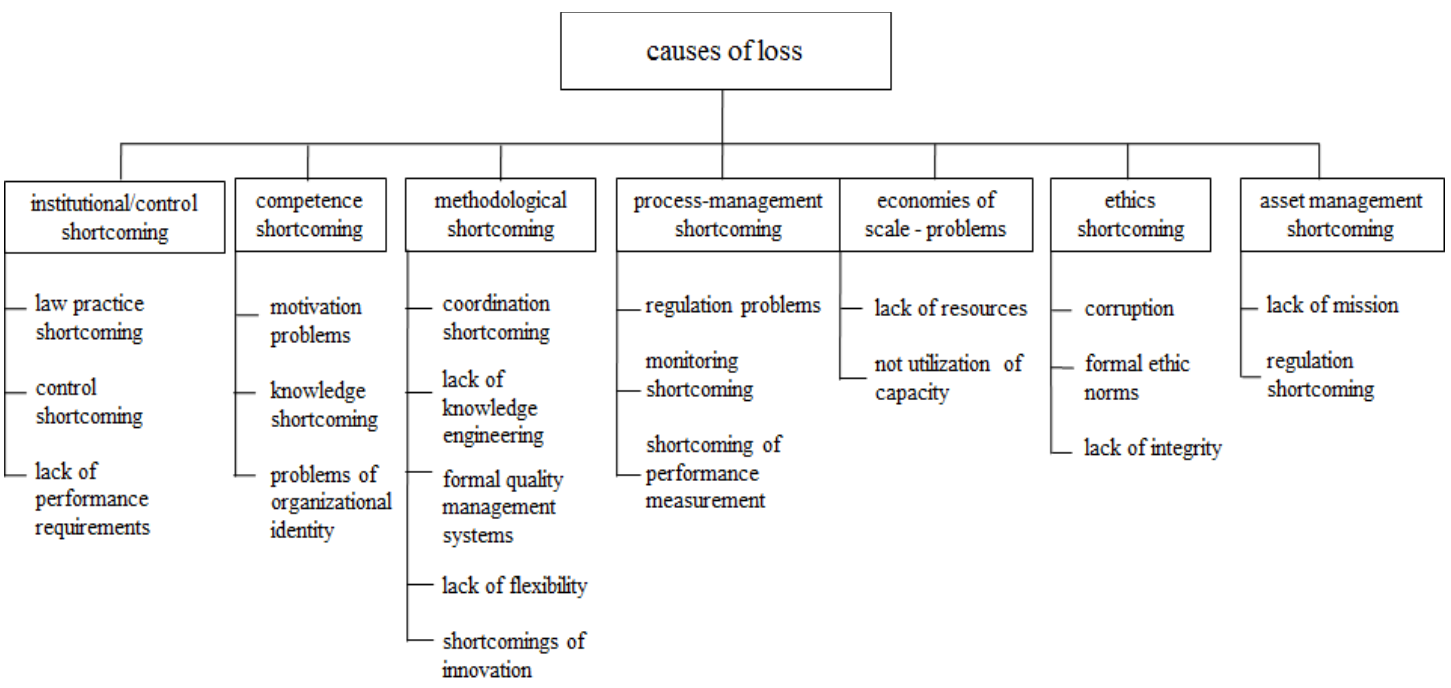

Figure 4. Factors reducing efficiency by public utility organizations

Source: own compilation

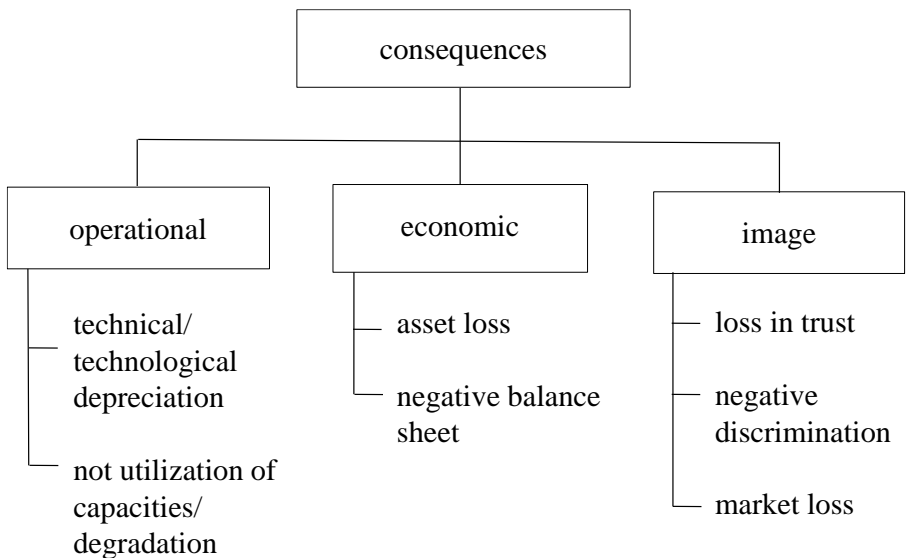

Figure 5. Consequences of loss 
Source: own compilation

The external and internal causes have mostly multiplicative effects, which can sometimes intensify each other, and this can have a negative influence both on the efficiency and on the social effects of the organization (Figure 5).

\section{The performance measurement of public utility organizations}

There are several aspects in the literature to define organizational performance. Most of these mention as important the efficiency to achieve goals, and the economic aspects (used expenditures for the achieved results) (Kocziszky - Veresné Somosi, 2015).

According our opinion the public utility organizations are systems with limited resources, which have some inputs and outputs. But the outputs are not the same as their effects. While the output can be measured basically with values (like properties and total balance sheet, etc.) or natural dates (quantitative and qualitative parameters); the welfare effects can be measured through the change of the life quality (the differences can be seen in the case of Hungary e.g. in Szendi, 2016) or the availability of public services (e.g.: in share of population, etc.) or environmental pressure (Figure 6).

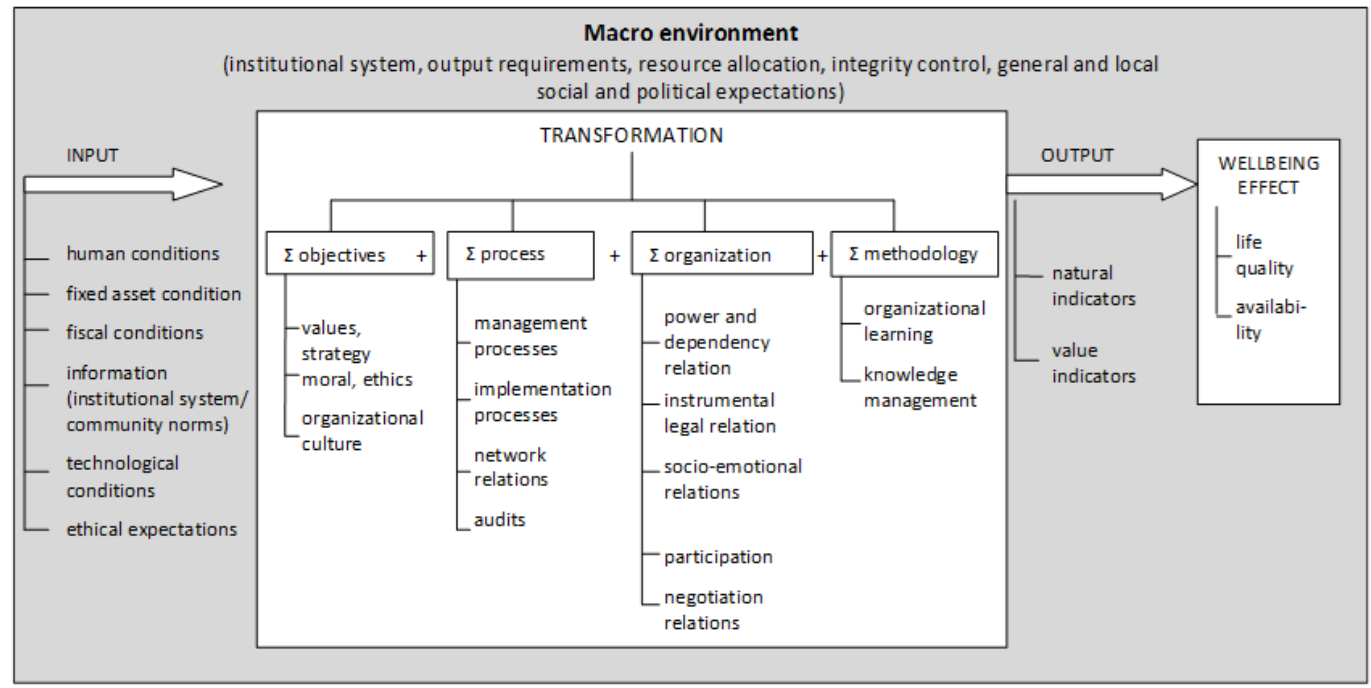

Figure 6. Influential factors of public utility organizations

Source: own compilation

\section{The performance management process of the public utility organizations}

Former the terminology and methods applied for the analysis of public utility organizations' performance were the same as applied in the enterprise level. The researchers have only recognized from the 90 s that these types of organizations have got specific performance management system, which has to be in a concordance with the requirements of "goodstate" and "good-governance" concept (Schedler - Proeller, 2011).

The function of the public utility organizations' performance management:

defining development objectives and expectations which are relevant for the organization's performance,

follow up of the interventions which are made to meet the performance expectations,

defining the development needs,

defining and developing the individual performances which are relevant for the organization. 
The performance management process of the public utility organizations can be separated into five steps (Figure 7):

defining the organization's mission, objectives and performance standards,

estimating the initial conditions/situation, and building a value map,

comparing targets and facts, and defining the performance expectations,

elaborating the directions of interventions,

feedback of the interventions' results, implementing possible corrections.

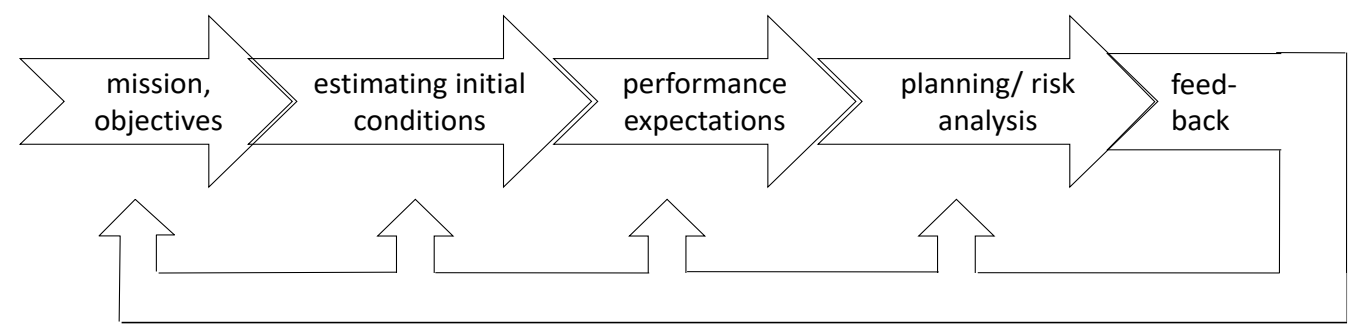

Figure 7. Logical process of performance management by public utility organizations

Source: own compilation

\subsection{Defining the organization's mission, objectives and performance standards}

In the social public thinking, and social needs (e.g.: rights, security, well-being, etc.) the ethical expectations have an outstanding role by the definition of the public utility organizations' mission (Domokos - Pulay, 2015). According to our opinion the operation of a public utility organization can be sustainable when it follows the ethics; so where the institutional system does not abuse with its rights, and which solves the problems through real innovation and not with budgetary tricks, etc. (Figure 8).

It is important to emphasize this, because the value system which was created through the effects of the geopolitical changes happened after 1989 is eclectic; at the same time contains elements of hedonist thinking and ideology which makes actions for public well-being. The value system is a stable point; with a help of it the mission and objective system can be defined. 


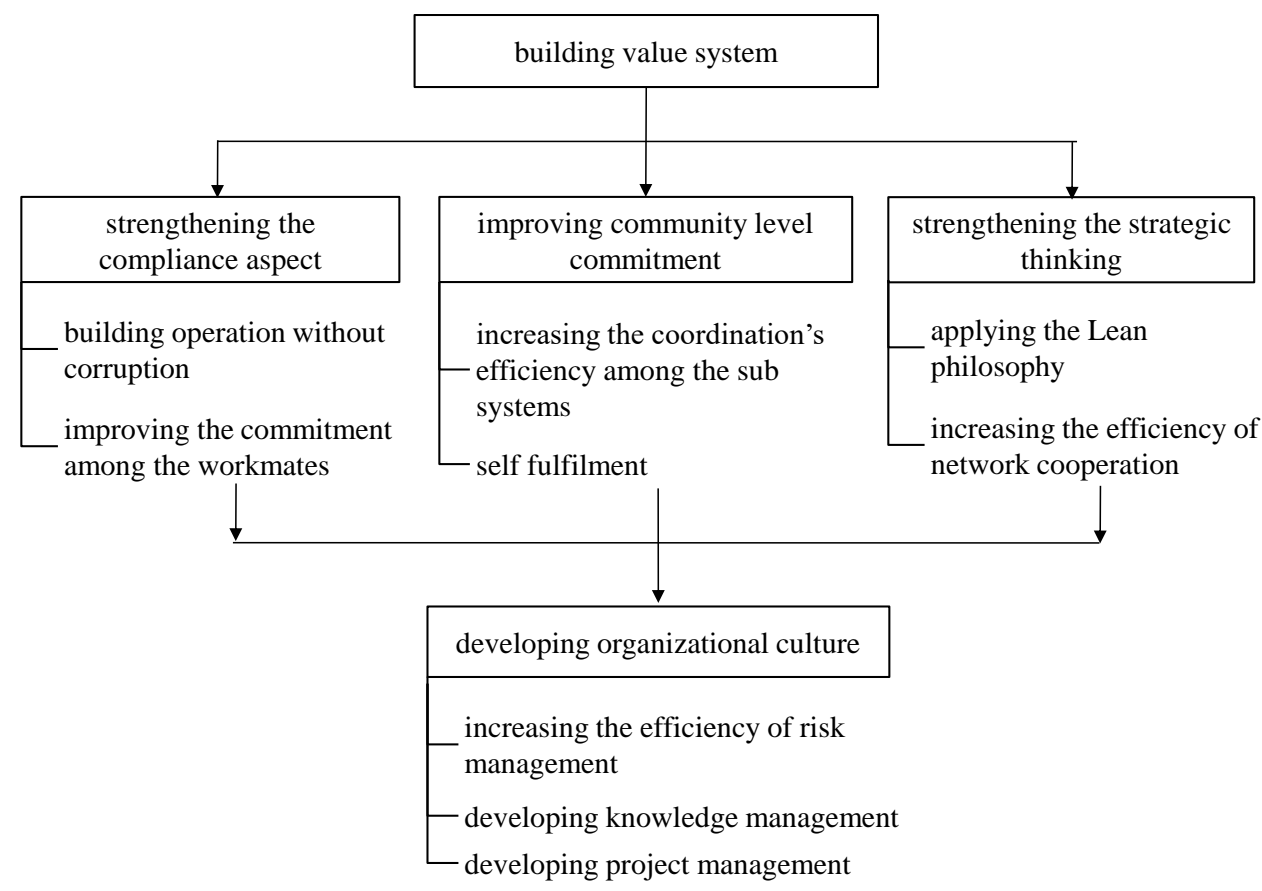

Figure 8. Goal/ Objectives tree

Source: own compilation

The organizations using public resources have to define parallel with their mission also the norms, which define the area of their operations.

\subsection{Estimating the initial conditions}

The objective of the initial conditions' estimation is positioning the public utility organization, and examining the factors which can hinder the operational efficiency.

\section{The methodology of estimation}

We have elaborated a questionnaire to analyse the efficiency of the operation, which has a system approach, and which is adequate beside the analysis of input and output elements also for the analysis of transformation capacity.

The test is appropriate for the examination at a sum of 14 main directions, and 48 sub dimensions. It contains in the case of sub dimensions at a sum of 570 questions (Figure 9).

The main advantages of this questionnaire are:

their questions have a common, unified approach, and their application is flexible, the questions can be complemented according the organizational and sectoral characteristics;

the questions can relieve the applicant from the memoriter (he/she has to concentrate instead of "what should I examine" for the "how to evaluate" question);

the questionnaire can be repeated based on the same aspects, which gives an opportunity for making chronological comparisons.

\section{Evaluating the questionnaire}


The evaluation of the questions can be made based on a five point ordinal scale with points from 1 to 5 (Table 2, 3 and 4). As a result of the points the value and median of a given sub dimension can be calculated.

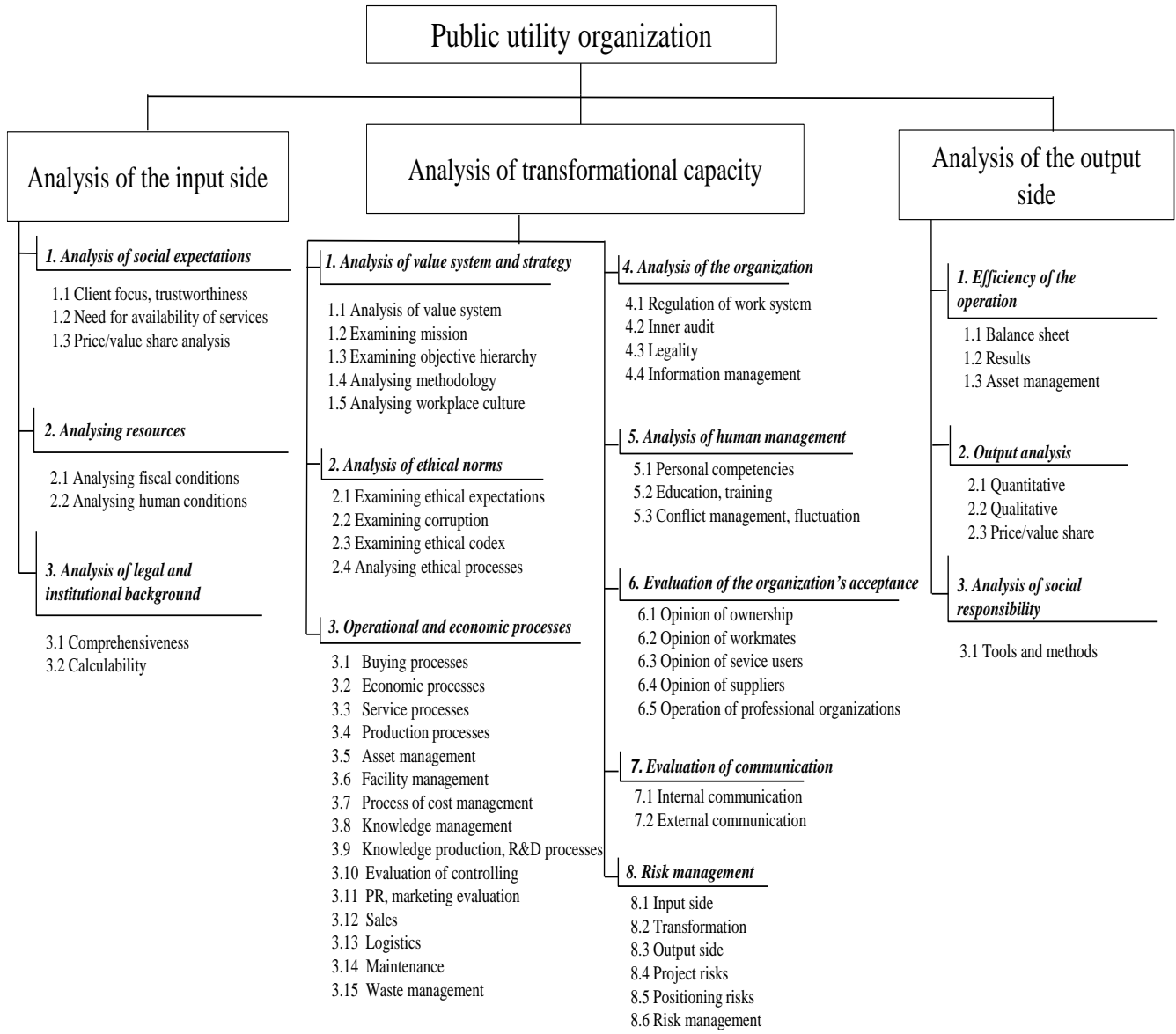

Figure 9. The questionnaire structure for public utility organizations

Source: own compilation

Table 2: An example of the test's structure

1.1. Analysis of the value system

\begin{tabular}{|l|l|l|l|l|l|l|}
\hline \multirow{2}{*}{ No. } & \multirow{2}{*}{ Examined area } & Evaluation of the organization & \multirow{2}{*}{} \\
\cline { 4 - 8 } & & 1 & 2 & 3 & 4 & 5 \\
\hline 1.1 .1$. & Is the value system of the organization declared? & & & & & \\
\hline 1.1 .2$. & How actual is the value system of the organization? & & & & & \\
\hline 1.1.3. & $\begin{array}{l}\text { What kind of concordance can be found between the } \\
\text { activity of the top management and value system of } \\
\text { the organization? }\end{array}$ & & & & & \\
\hline 1.1 .4$. & $\begin{array}{l}\text { What quality has got the organization's value } \\
\text { hierarchy? }\end{array}$ & & & & & \\
\hline 1.1.5. & How much the organization's values are & & & & & \\
\hline
\end{tabular}




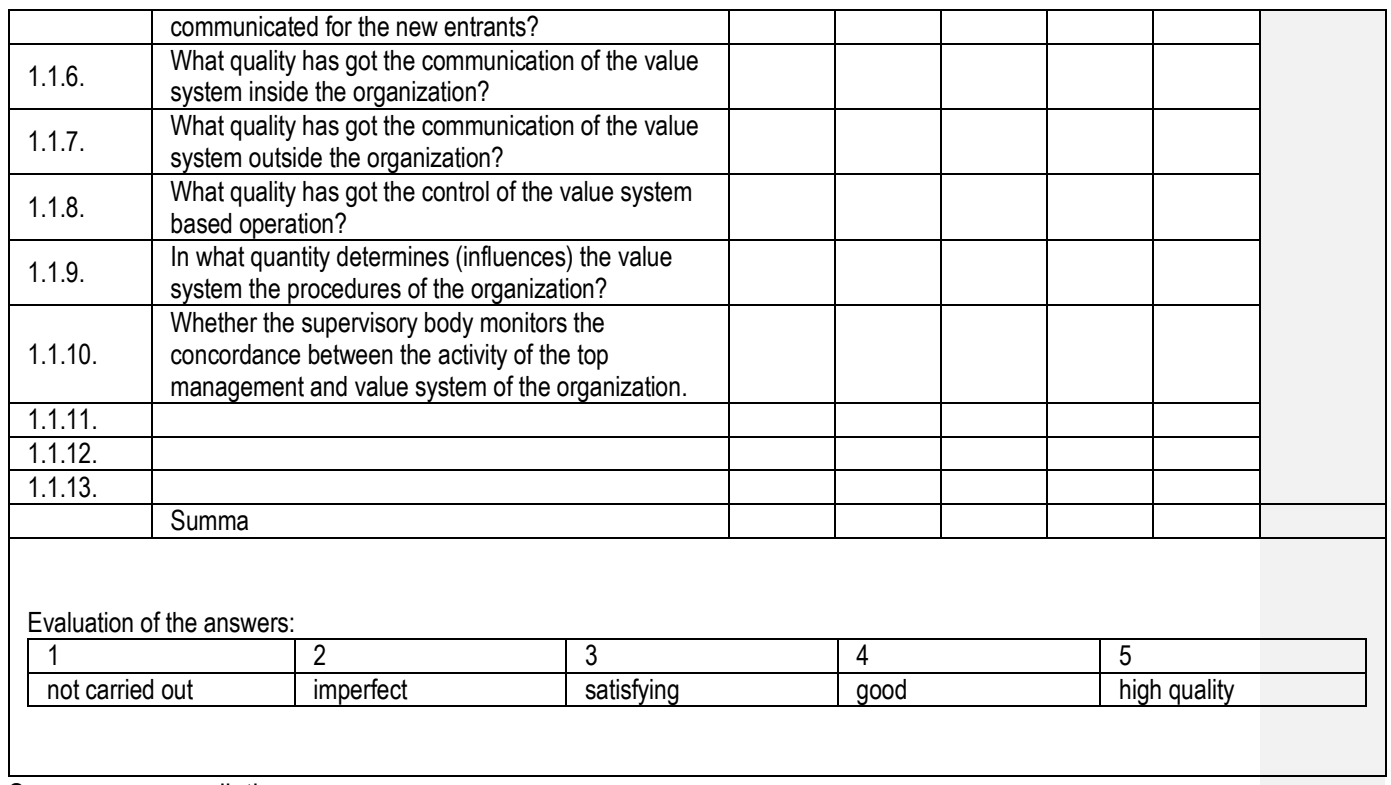

Source: own compilation

The examined organization's input transformation and output capabilities analysis can be carried out (based on the test's answers) through factor and cluster analysis, because the evaluation is based on quantitative and qualitative (more or less subjective values) indicators. The cluster analysis gives an opportunity to compare the enterprises acting in the same sector, and also for evaluating their positions.

Table 3: An example of the output analysis' test

\subsection{Analysis of asset management's efficiency}

\begin{tabular}{|c|c|c|c|c|c|c|c|}
\hline \multirow{2}{*}{ No. } & \multirow{2}{*}{ Examined area } & \multicolumn{5}{|c|}{ Evaluation of the organization } & \multirow{2}{*}{$\Sigma$} \\
\hline & & 1 & 2 & 3 & 4 & 5 & \\
\hline 1.3.1. & Is the property of the organization clear? & & & & & & \\
\hline 1.3.2. & $\begin{array}{l}\text { Has the organization an asset management } \\
\text { strategy? }\end{array}$ & & & & & & \\
\hline 1.3.3. & $\begin{array}{l}\text { Is there a consonance among the objectives of the } \\
\text { asset management strategy? }\end{array}$ & & & & & & \\
\hline 1.3.4. & $\begin{array}{l}\text { Is there a consonance between the organization's } \\
\text { development and asset management strategy? }\end{array}$ & & & & & & \\
\hline 1.3.5. & $\begin{array}{l}\text { Is the asset management strategy of the organization } \\
\text { structured into one-year plans? }\end{array}$ & & & & & & \\
\hline 1.3.6. & $\begin{array}{l}\text { Is the asset management of the organization } \\
\text { evaluated yearly? }\end{array}$ & & & & & & \\
\hline 1.3.7. & $\begin{array}{l}\text { Is the asset management of the organization } \\
\text { regulated? }\end{array}$ & & & & & & \\
\hline 1.3.8. & Is the right above the assets regulated? & & & & & & \\
\hline 1.3.9. & $\begin{array}{l}\text { Is there a helping informatics system which deals } \\
\text { with the assets' register and management? }\end{array}$ & & & & & & \\
\hline 1.3.10. & $\begin{array}{l}\text { Is the change of assets evaluated based on } \\
\text { analytics? }\end{array}$ & & & & & & \\
\hline 1.3.11. & Is the stock-taking process regulated? & & & & & & \\
\hline 1.3.12. & Are the asset management's risks well analysed? & & & & & & \\
\hline
\end{tabular}




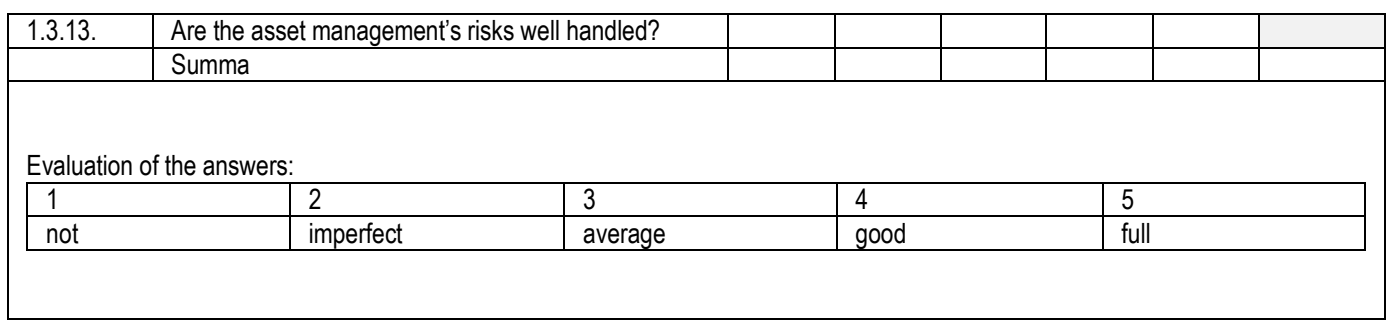

Source: own compilation

Table 4: An example of the input analysis' questions

1.1. Client focus, trustworthiness

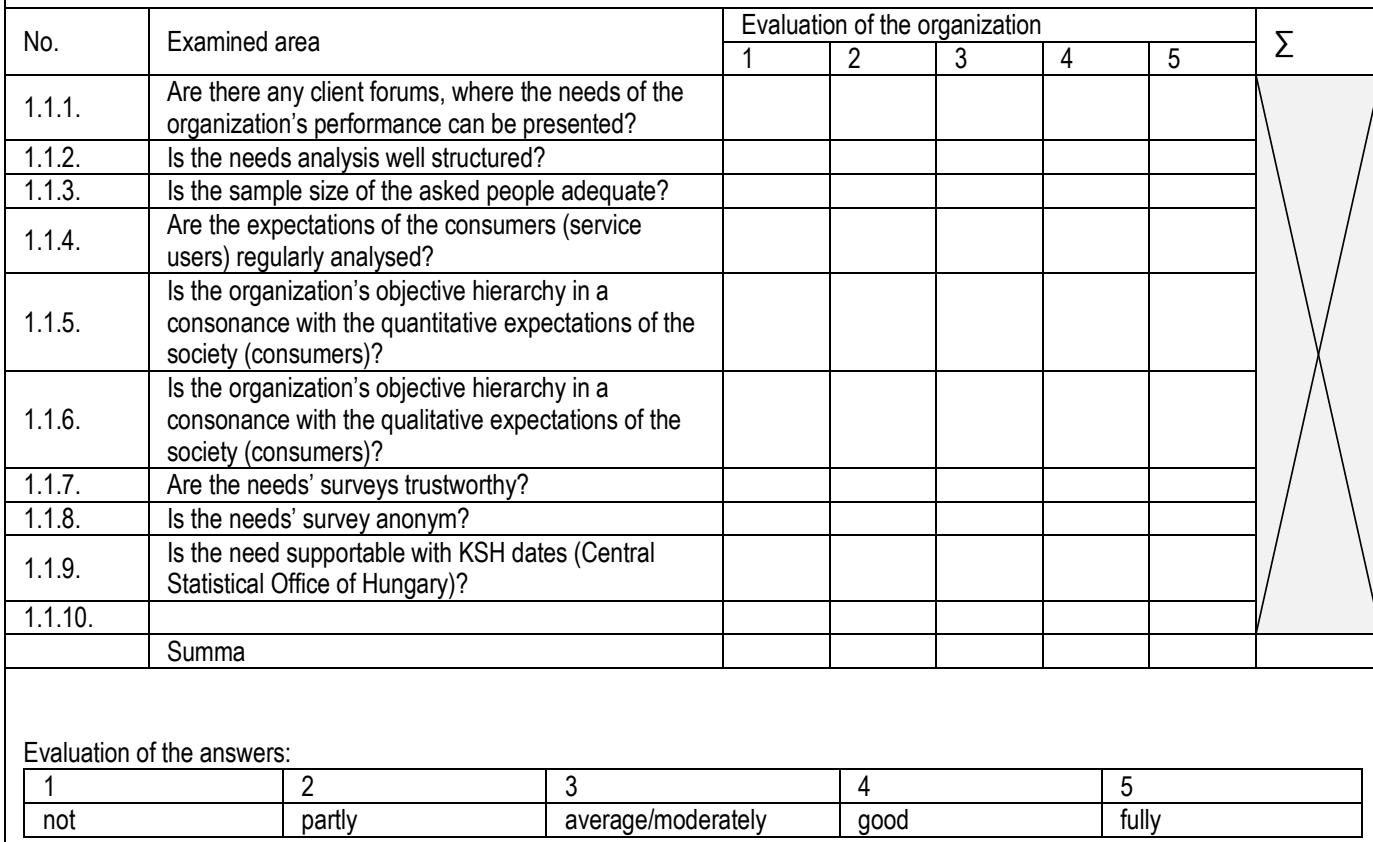

\section{Source: own compilation}

\subsection{Defining the performance expectations}

In the case of the public utility organizations there is a problem with the performance expectations, which are imprecise and incomplete. There are some parts/requirements of the organization which should be among the performance expectations, these are:

property situation (increase in the properties, asset management, etc.);

environmental pressure;

economic activity (employment, balance sheet, etc.). 


\subsection{Planning, risk analysis}

The national public utility organizations and their business plans are created in some times in the old plan-bargain aspect, while the potential risks are not smaller as in the competitive sphere (Table 5).

Table 5: Risk elements

\begin{tabular}{|l|l|l|}
\hline Risk & Type & Causes/Reasons \\
\hline No. & political & $\begin{array}{l}\text { change in the social, cultural conditions } \\
\text { lack of social minimum } \\
\text { inconsistent political institutional system }\end{array}$ \\
\hline 2. & financial/economic & $\begin{array}{l}\text { lack of resources } \\
\text { depreciation } \\
\text { planning shortcomings (under-/overestimation) } \\
\text { lack in financing } \\
\text { shock-effects }\end{array}$ \\
\hline 3. & legal & $\begin{array}{l}\text { shortcomings of regulation } \\
\text { lack of legal harmonization } \\
\text { lack of implementation decision }\end{array}$ \\
\hline 4. & ethics/human & $\begin{array}{l}\text { corruption } \\
\text { incompetence } \\
\text { lack (shortcoming) of value system } \\
\text { irresponsibility } \\
\text { lack of ethical codex }\end{array}$ \\
\hline 5. & environmental & $\begin{array}{l}\text { environmental damage } \\
\text { deregulation of business processes } \\
\text { organizational deregulation } \\
\text { deregulation of management processes }\end{array}$ \\
\hline 6. & operational/business &
\end{tabular}

Source: own compilation

According to our opinion the compliance culture is more modest.

\subsection{Feedback}

The performance management is not one fold, but a permanent task, which has got some parts like: the review of achieved results, the comparison with the plans, analysing the differences and feedback.

\section{Conclusions}

The efficient working organizational structure is an important criterion in the operation of the good state's concept. The performance management aspect is an important (but not sufficient) condition of this in the case of public utility organizations.

The performance management is a process in which the leaders of the organization define what the actors have to make for fulfilling the strategic goals; beside the individual performance to increase organizational performance. The described model has a complex viewpoint, which unseals the planning of organizational performance to individual performance requirements. It also combines the individual performance evaluation with the motivation system and competence development.

The presented model has a heterodox character; the novelty is its complexity, system and value approach, and the adaptation capacity of business solutions.

\section{References}

[1] CEC (1996): Európai közérdekű szolgáltatások (European public services). 96/6/281/03 Official Journal of the European Union, Brussels.

[2] Domokos L. - Pulay Gy. (2015): Strengthening integrity against Corruption: The Integrity Project of the StateAudit Office of Hungary. International Journal of Government Auditing, Vol. 42. No. 3. pp. 22-25.

[3] Kocziszky Gy. - Veresné Somosi M. (2015): The Value Map of the Welfare Public Administration and the Model of ITS measurability. Turkey proceedings Booklet. Istanbul, pp. 140-146. 
[4] Lienhard A. - Ladner A. - Ritz A. - Steiner R. (2005): 10 Jahre New Public Management in der Schweiz: Bilanz, Irrtümer und Erfolgsfaktoren. Haupt Verlag, Bern, p. 245.

[5] Reinermann H. (2000): Neues Politik- und Verwaltungsmanagement: Leitbild und theoretische Grundlagen (http://www.dhv-speyer.de/rei/publica/online/spah130.pdf) Speyerer Arbeitshefte 130, Speyer. Downloaded: 21.10.2016.

[6] Schedler K. - Proeller I. (2011): New Public Management. Haupt Verlag, Bern.

[7] Szendi D. (2016): Territorial differences of the life quality, as a complex indicator in Germany and Hungary. DETUROPE - the Central European Journal of Regional Development and Tourism, Vol. 8, No. 2. pp. 23-34. 